1001001110000 Dol00010101000 00001000100 11001001

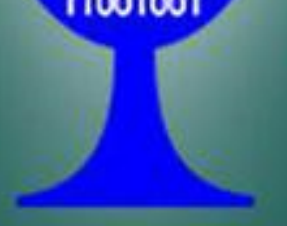

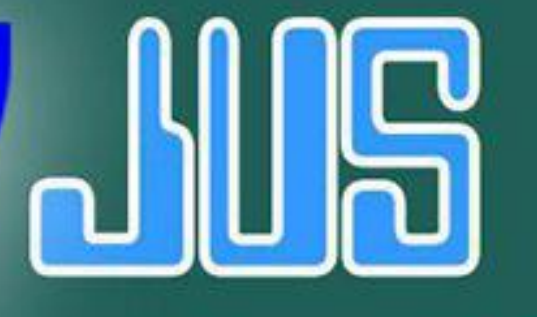

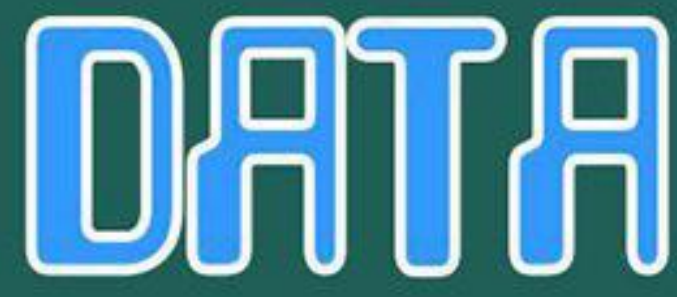

\section{Jurnal Sistem Informasi}
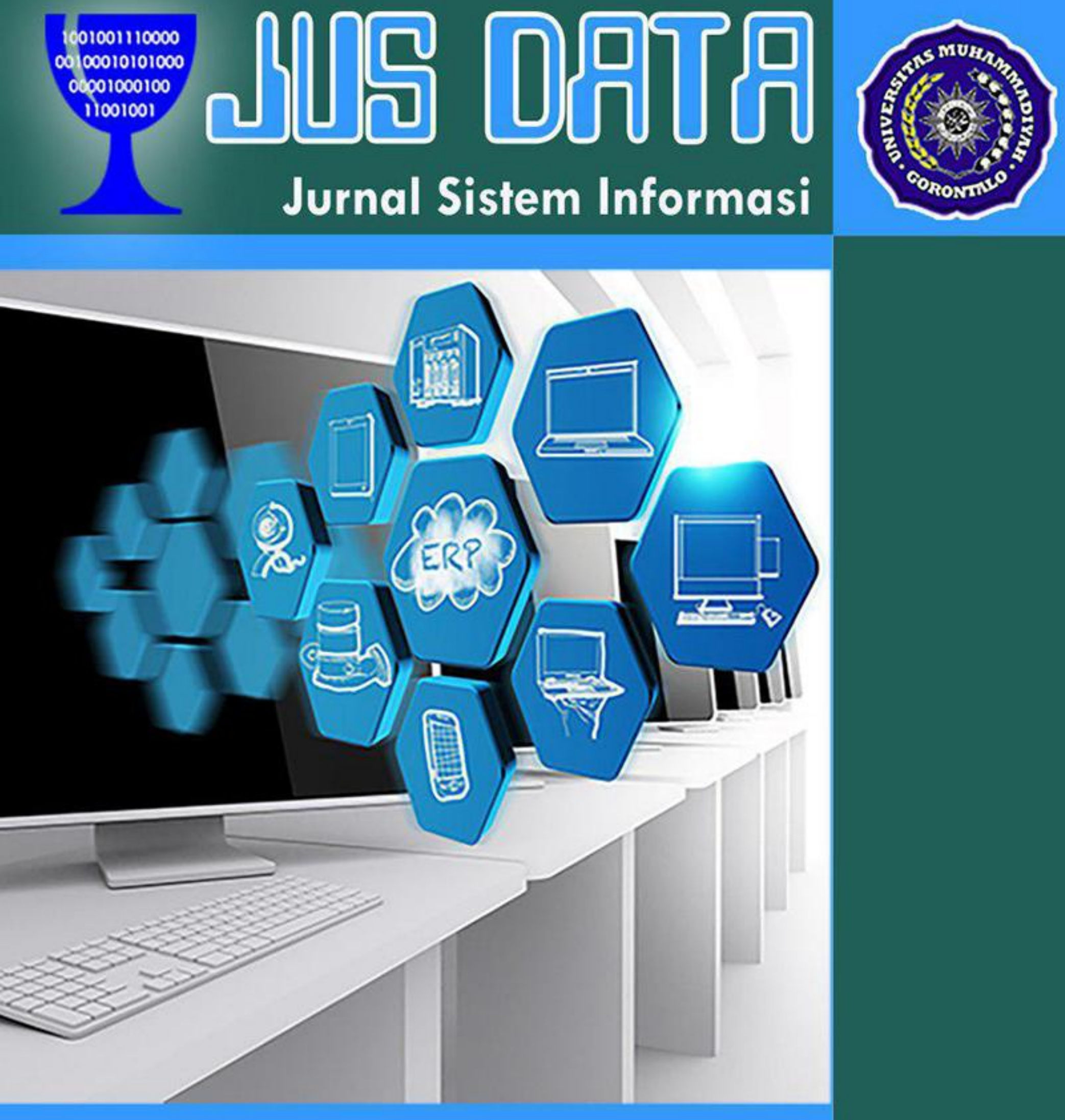

ISSN : 2301-5748 Volume : 5 Nomor : $1 \quad$ Juni 2017

PROGRAM STUDI SISTEM INFORMASI UNIVERSITAS MUHAMMADIYAH GORONTALO 


\section{DAFTAR ISI}

SISTEM INFORMASI MUTASI PEGAWAI PADA DINAS PENDIDIKAN DAN KEBUDAYAAN KABUPATEN GORONTALO

Alter Lasarudin, M.Kom, Darwis Ayuba

SISTEM PENDUKUNG KEPUTUSAN SELEKSI PENYULUH PERTANIAN MENGGUNAKAN METODE ANALITYCHAL HIERARCHY PROCESS

Wahyudin Hasyim, M.Kom, Akbar Hidayat

SISTEM INFORMASI PENJUALAN TIKET BERBASIS MULTIUSER PADA WATERBOOM TIARA PARK DI GORONTALO

Irawan Ibrahim, ST, M.Kom, Alfid Ishak.

SISTEM INFORMASI POLIKLINIK TERPADU

Syahrial, M.Kom

PERANCANGAN SISTEM PENJADWALAN KULIAH DAN UJIAN SKRIPSI PROGRAM STUDI SISTEM INFORMASI BERBASIS WEB

Rubiyanto Maku, Zilfadlia Inombi

ANALISIS PROSES BISNIS KENAIKAN PANGKAT PADA DINAS

PERTANIAN, PERKEBUNAN DAN KETAHANAN PANGAN

KABUPATEN BONE BOLANGO

Rizal Lamusu, S.Kom, MT, Noprianti Bakari 


\title{
SISTEM INFORMASI POLIKLINIK TERPADU
}

\author{
Syahrial, M.Kom
}

Program Studi Sistem Informasi, Fakultas Sains Teknologi Universitas Muhammadiyah Gorontalo

Email : syahrial@umgo.ac.id

\begin{abstract}
Abstrak
Pengelolaan poliklinik saat ini umumnya sudah menggunakan sistem terkomputerisasi. Namun, sistem yang sudah ada hampir seluruhnya dibuat terpisah atau dalam bentuk sistem yang berdirisendiri. Pengelolaan data klinik, data keuangan, data apotik dan data antrian dipakai dengan sistem yang berbeda-beda. Berdasarkan penelitian-penelitian sebelumnya telah ada sistem informasi klinik, rekam medis, dan rawat inap/jalan namun aplikasi tersebut masih berdiri sendiri. Terdapat banyak rujukan penelitian sebelumnya yang hanya mengelolah data klinik dalam hal ini rekam medis dan data-data apotik. Pengelolaan keuangan belum pernah dipadukan dalam sistem yang sama khususnya untuk sistem informasi poliklinik. Solusi yang diberikan oleh peneliti dengan merancang dan membangun sistem yang memadukan pengelolaan data klinik, data perawatan, data keuangan, data apotik, serta data antrian dalam satu sistem yang terpadu. Pengembangan sistem memanfaatkan teknologi web seperti: bahasa pemrograman PHP, HTML5, CSS, dan Javascript. Penyimpanan data dirancang dengan memanfaatkan database server MySQL. Pemanfaatan teknologi web ini memungkinkan sistem berjalan ringan dan dapat diakses baik secara intranet maupun internet.
\end{abstract}

Kata kunci: sistem informasi, poliklinik, terpadu, teknologi web

\section{PENDAHULUAN}

Klinik merupakan tempat untuk memberikan pelayanan medik jangka pendek, bagi semua orang yang menderita sakit atau luka sesuai dengan sakit yang dideritanya. Menurut [1] tugas Klinik adalah melaksanakan upaya kesehatan berdaya guna dan berhasil guna, serasi dan terpadu dengan upaya peningkatan dan pencegahan serta melaksanakan upaya rujukan. Fungsi klinik itu sendiri adalah tempat menyelenggarakan pelayanan medik, pelayanan penunjang dan pelayanan pencegahan penyakit.

Klinik sebagai salah satu institusi pelayanan kesehatan umum membutuhkan keberadaan sistem informasi yang akurat dan handal, serta cukup memadai untuk meningkatkan pelayanan kesehatan kepada para pasien serta lingkungan yang terkait lainnya. Pengelolaan data di institusi pelayanan kesehatan merupakan salah satu komponen yang penting dalam mewujudkan sistem informasi klinik.
Sistem informasi yang telah dikembangkan seperti aplikasi rawat jalan [2], sistem poliklinik [3], sistem laboratorium klinik [4], sistem informasi klinik gigi [5], sistem informasi klinik [6], sistem informasi poliklinik [7], sistem administrasi klinik [8], sistem informasi poliklinik [9], analisis kebutuhan perencanaan sistem informasi kesehatan [10], sistem antrian klinik [11], sistem rawat inap [12], sistem klinik praktik dokter [13], aplikasi rekam medis [14], sistem informasi klinik [15], dan perancangan sistem informasi rekam medis [16] masih berdiri sendiri. Sistemsistem tersebut umumnya tidak memasukkan pengelolaan keuangan secara akuntansi serta pengelolaan obat belum memenuhi standar pengelolaan apotik.

Berdasarkan uraian diatas tentang permasalahan yang ada pada pembahasan sebelumnya serta berdasarkan penelitian-penelitian sebelumnya maka perlu untuk dibangun sistem poliklinik yang memadukan segala fasilitas dari system sebelumnya. Sistem terpadu ini dapat menjadi rujukan 
untuk

mengimplementasikan

pengelolaan poliklinik maupun fasilitas medis lainnya yang terkomputerisasi.

\section{TINJAUAN PUSTAKA}

\section{Sistem Informasi}

[17] menyatakan bahwa sistem adalah suatu jaringan kerja dari prosedur yang saling berhubungan, berkumpul bersama-sama untuk melakukan suatu kegiatan atau untuk menyelesaikan suatu sasaran yang tertentu. Menurut Davis Informasi adalah data yang diolah menjadi bentuk yang lebih berarti bagi penerima dan bermanfaat dalam pengambilan keputusan saat ini atau mendatang dan lebih berarti bagi yang menerimanya. Menurut [18] mengemukakan bahwa "Sistem Informasi (information system) secara teknis dapat didefinisikan sebagai sekumpulan komponen yang saling berhubungan mengumpulkan atau mendapatkan, memproses, menyimpan dan mendistribusikan informasi untuk menunjang pengambilan keputusan dan pengawasan dalam suatu organisasi”.

\section{Sistem Informasi Klinik}

Sistem informasi klinik merupakan sebuah sistem informasi yang di dalamnya meliputi proses penyimpanan dan pengambilan informasi dalam membantu kegiatan pelayanan langsung pada pasien yang bertujuan memperoleh hasil akurat, mempercepat pelayanan dan menghemat tenaga. Pelayanan langsung tersebut meliputi: membantu dalam mendiagnosa suatu penyakit, membantu dalam monitoring perkembangan pasien, dan membantu dalam penyesuaian terapi. Tujuan sistem informasi klinik adalah untuk memperoleh hasil yang akurat dan tepat sesuai dengan kebutuhan instansi tersebut. Tujuan lainnya adalah mempercepat pelayanan guna mempermudah dalam memberikan pelayanan sehingga pelayanan yang diberikan bisa efektif dan efisien serta menghemat tenaga

Jenis sistem informasi klinik terbagi 3(tiga), sebagai berikut:

a. Komputer pembantu diagnose, pengumpulan data baik dari anamnesa, pemeriksaan fisik, laboratorium yang diperlukan. Penilaian atas data itu sehingga bisa dibandingkan dengan normal dan cirri khusus suatu penyakit, sehinggan akan membantu menentukan diagnose. Contoh: Sistem anamnesa otomatis pasien dengan memasukan keluhan yang dirasa pada komputer sehingga muncul beberapa difrensial diagnose untuk penanganan. Interprestasi EKG, Hasil grafik EKG, selain gambarnya juga ada arti dari gambaran itu seperti aritmia, estedrepesi dan juga ada interprestasi yang berupa gambaran beberapa DD atau dari penyakit.

b. Komputer pembantu pengobatan dan tindak lanjut, jenis ini akan membantu patokan terapi dan jadwal yang harus dipenuhi. Biasanya untuk terapi jangka panjang dan sensitive misalnya terapi kanker dengan radiologi dan kemoterapi. Contoh: Computer yang berisi gambaran protocol pengobatan suatu penyakit dan upaya untuk mengingatkan bila sampai pada waktunya, Computerized Patient Follow Up sistem.

c. Sistem pemantau pasien, sistem ini akan memantau pasien terus menerus tanpa lelah seperti halnya manusia. Hal ini penting diterpkan pada pelayanan seperti: ICU (Intensive Care Unit), Kamar operasi, ICCU (intensive Cardive Care Unit)

d. Sistem informasi rekam medis, termasuk dalam sistem informasi ini adalah hal-hal yang berhubungan 
dengan pengelolaan data yang ada pada status pasien, kemudian termasuk pula bagaimana pengelolaan dan pencarian kembali.

\section{Rekam Medis}

Pengertian rekam medis mengacu pada [19] adalah berkas yang berisikan catatan dan dokumen tentang identitas pasien, pemeriksaan, pengobatan, tindakan dan pelayanan lain kepada pasien pada sarana pelayanan kesehatan. Pengertian lainnya menurut [20] dalam penjelasan Pasal 46 ayat (1) UU Praktik Kedokteran, yang dimaksud dengan rekam medis adalah berkas yang berisi catatan dan dokumen tentang identitas pasien, pemeriksaan, pengobatan, tindakan dan pelayanan lain yang telah diberikan kepada pasien.

\section{METODOLOGI}

Tahapan penelitian digambarkan pada gambar 3.1 dibawah.

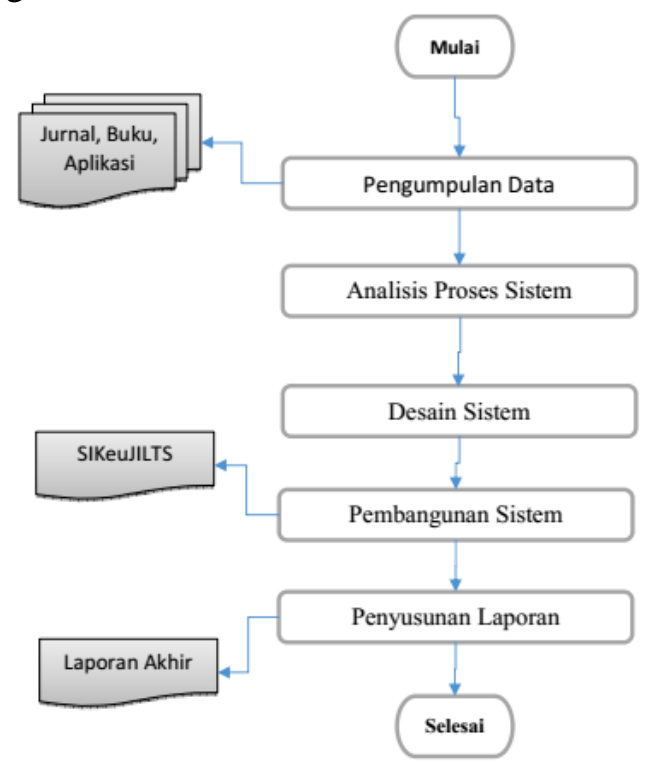

Gambar 1 Tahapan Penelitian

Metode yang digunakan pada penelitian ini adalah metode penelitian eksperimen dengan menggunakan metode pengembangan sistem prototype. Peneliti menyesuaikan metode pengembangan sistem prototype sesuai kebutuhan.

HASIL DAN PEMBAHASAN Pengumpulan Data
Kepustakaan digunakan untuk mencari literatur-literatur yang berhubungan dengan pengelolaan keuangan. Pengumpulan data digunakan untuk mendapatkan arsitektur sistem informasi akuntansi dari hasil pengembangan dalam penelitian sebelumnya.

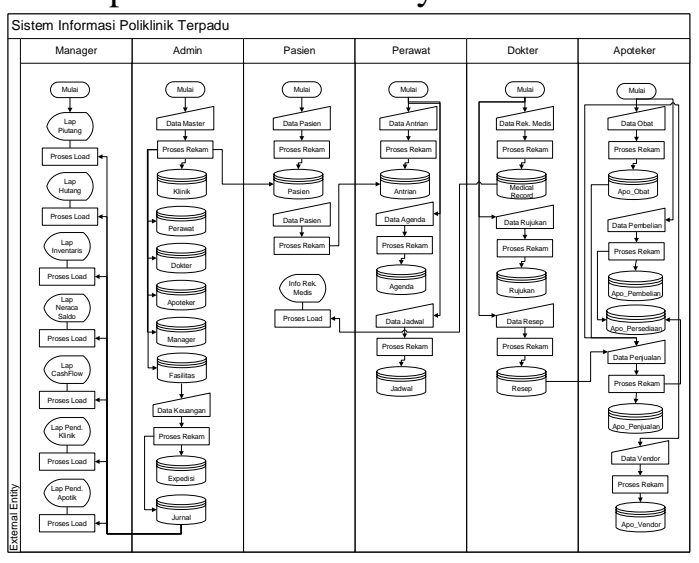

Gambar 3.2 Flowchart Proses Sistem ePoliklinik

\section{Analisis Proses Sistem}

\section{Kebutuhan Fungsional}

Berdasarkan data yang didapat pada tahapan pengumpulan data, peneliti mengidentifikasi kebutuhan fungsional sistem akuntansi terpadu yang dirangkum dalam tabel 3.1 dibawah.

Tabel 3.1 Daftar Kebutuhan Fungsional

\begin{tabular}{|c|c|c|c|c|c|}
\hline $\begin{array}{l}\mathrm{N} \\
\mathrm{O}\end{array}$ & $\begin{array}{l}\text { Fung } \\
\text { siona } \\
1\end{array}$ & $\begin{array}{l}\text { Masuka } \\
\text { n }\end{array}$ & $\begin{array}{l}\text { Pro } \\
\text { ses }\end{array}$ & $\begin{array}{l}\text { Kelua } \\
\text { ran }\end{array}$ & $\begin{array}{l}\mathrm{K} \\
\text { et }\end{array}$ \\
\hline 1 & $\begin{array}{l}\text { Dapa } \\
\mathrm{t} \\
\text { meng } \\
\text { elola } \\
\mathrm{h} \\
\text { data } \\
\mathrm{klini} \\
\mathrm{k}\end{array}$ & $\begin{array}{l}\text { Data } \\
\text { Klinik, } \\
\text { data } \\
\text { fasilitas, } \\
\text { data } \\
\text { dokter, } \\
\text { data } \\
\text { perawat, } \\
\text { data } \\
\text { apoteker } \\
\text {, data } \\
\text { pasien, } \\
\text { antrian }\end{array}$ & $\begin{array}{l}\text { Sim } \\
\text { pan } \\
\text { Up } \\
\text { date } \\
\text { Del } \\
\text { ete }\end{array}$ & $\begin{array}{l}\text { Infor } \\
\text { masi: } \\
\text { klinik } \\
\text { f } \\
\text { fasilit } \\
\text { as, } \\
\text { dokte } \\
\text { r, } \\
\text { peraw } \\
\text { at, } \\
\text { apote } \\
\text { ker, } \\
\text { pasie } \\
\text { n } \\
\text { serta } \\
\text { antria } \\
\text { n }\end{array}$ & \\
\hline
\end{tabular}




\begin{tabular}{|c|c|c|c|c|}
\hline 2 & $\begin{array}{l}\text { Dapa } \\
\mathrm{t} \\
\text { meng } \\
\text { elola } \\
\mathrm{h} \\
\text { data } \\
\text { apoti } \\
\mathrm{k}\end{array}$ & $\begin{array}{l}\text { Data } \\
\text { obat, } \\
\text { pembeli } \\
\text { an, } \\
\text { penjuala } \\
\text { n, dan } \\
\text { persedia } \\
\text { an }\end{array}$ & $\begin{array}{l}\text { Sim } \\
\text { pan } \\
\text { Up } \\
\text { date } \\
\text { Del } \\
\text { ete, } \\
\text { hitu } \\
\text { ng } \\
\text { pers } \\
\text { edia } \\
\text { an }\end{array}$ & $\begin{array}{l}\text { Infor } \\
\text { masi: } \\
\text { obat, } \\
\text { pemb } \\
\text { elian, } \\
\text { penju } \\
\text { alan, } \\
\text { dan } \\
\text { perse } \\
\text { diaan }\end{array}$ \\
\hline 3 & $\begin{array}{l}\text { Mam } \\
\text { pu } \\
\text { meng } \\
\text { elola } \\
\text { h } \\
\text { data } \\
\text { medi } \\
\text { s }\end{array}$ & $\begin{array}{l}\text { Data } \\
\text { perawat } \\
\text { an, data } \\
\text { penyakit } \\
\text { pasien, data } \\
\text { data } \\
\text { rekam } \\
\text { medis, } \\
\text { data } \\
\text { resep, } \\
\text { dan data } \\
\text { rujukan }\end{array}$ & $\begin{array}{l}\text { Sim } \\
\text { pan } \\
\text { Up } \\
\text { date } \\
\text { Del } \\
\text { ete }\end{array}$ & $\begin{array}{l}\text { Infor } \\
\text { masi: } \\
\text { peraw } \\
\text { atan, } \\
\text { penya } \\
\text { kit, } \\
\text { pasie } \\
\text { n, } \\
\text { rekam } \\
\text { media } \\
\text {, } \\
\text { resep } \\
\text { dan } \\
\text { rujuk } \\
\text { an }\end{array}$ \\
\hline 4 & $\begin{array}{l}\text { Mam } \\
\text { pu } \\
\text { meng } \\
\text { elola } \\
\mathrm{h} \\
\text { data } \\
\text { rawat } \\
\text { jalan } \\
\text { dan } \\
\text { rawat } \\
\text { inap }\end{array}$ & $\begin{array}{l}\text { Data } \\
\text { perawat } \\
\text { an, data } \\
\text { ruangan, } \\
\text { data } \\
\text { pasien }\end{array}$ & $\begin{array}{l}\text { Sim } \\
\text { pan } \\
\text { Up } \\
\text { date } \\
\text { Del } \\
\text { ete }\end{array}$ & $\begin{array}{l}\text { Infor } \\
\text { masi: } \\
\text { peraw } \\
\text { atan, } \\
\text { ruang } \\
\text { an, } \\
\text { dan } \\
\text { pasie } \\
\text { n }\end{array}$ \\
\hline 5 & $\begin{array}{l}\text { Dapa } \\
\mathrm{t} \\
\text { meng } \\
\text { elola } \\
\mathrm{h} \\
\text { data } \\
\text { keua } \\
\text { ngan } \\
\text { secar } \\
\text { a } \\
\text { kaida } \\
\mathrm{h} \\
\text { akunt } \\
\text { ansi }\end{array}$ & $\begin{array}{l}\text { Data } \\
\text { akun, } \\
\text { data } \\
\text { ekspedis } \\
\text { i, data } \\
\text { jurnal }\end{array}$ & $\begin{array}{l}\text { Sim } \\
\text { pan } \\
\text { Up } \\
\text { date } \\
\text { Del } \\
\text { ete }\end{array}$ & $\begin{array}{l}\text { Infor } \\
\text { masi: } \\
\text { cashfl } \\
\text { ow, } \\
\text { nerac } \\
\text { a } \\
\text { saldo, } \\
\text { perub } \\
\text { ahan } \\
\text { modal } \\
\text { nerac } \\
\text { a } \\
\text { akhir, }\end{array}$ \\
\hline
\end{tabular}

\begin{tabular}{|c|c|c|c|c|}
\hline & & & & $\begin{array}{l}\text { piutan } \\
\text { g, } \\
\text { hutan } \\
\text { g, dan } \\
\text { invent } \\
\text { aris }\end{array}$ \\
\hline 6 & $\begin{array}{l}\text { Siste } \\
\text { m } \\
\text { dapat } \\
\text { diaks } \\
\text { es } \\
\text { dari } \\
\text { multi } \\
\text { platf } \\
\text { orm } \\
\text { atau } \\
\text { multi } \\
\text { siste } \\
\text { m } \\
\text { infor } \\
\text { masi. }\end{array}$ & $\begin{array}{l}\text { Sistem } \\
\text { berbasis } \\
\text { web }\end{array}$ & $\begin{array}{l}\text { PH } \\
\text { P, } \\
\text { My } \\
\text { SQ } \\
\text { L, } \\
\text { dan } \\
\text { Jav } \\
\text { ascr } \\
\text { ipt }\end{array}$ & $\begin{array}{l}\text { HTM } \\
\text { L5 }\end{array}$ \\
\hline
\end{tabular}

Pada tabel di atas berupa daftar kebutuhan fungsional yang harus dipenuhi oleh sistem informasi klinik terpadu. Kebutuhan tersebut diatas dijabarkan masukan, proses yang dapat dilakukan, serta keluaran dari masingmasing fungsional tersebut.

Tabel 3.2 Daftar Ekstenal Entity.

\begin{tabular}{|c|c|c|c|c|}
\hline $\begin{array}{l}\mathrm{N} \\
\mathrm{o}\end{array}$ & $\begin{array}{l}\text { En } \\
\text { tit } \\
y\end{array}$ & Masukan & $\begin{array}{l}\text { Pros } \\
\text { es }\end{array}$ & $\begin{array}{l}\text { Keluar } \\
\text { an }\end{array}$ \\
\hline 1 & $\begin{array}{l}\text { A } \\
\mathrm{d} \\
\mathrm{mi} \\
\mathrm{n}\end{array}$ & $\begin{array}{l}\text { Data } \\
\text { Klinik, } \\
\text { data } \\
\text { fasilitas, } \\
\text { data } \\
\text { dokter, } \\
\text { data } \\
\text { perawat, } \\
\text { data } \\
\text { apoteker, } \\
\text { data } \\
\text { pasien }\end{array}$ & $\begin{array}{l}\text { Sim } \\
\text { pan, } \\
\text { Upd } \\
\text { ate, } \\
\text { Dele } \\
\text { te }\end{array}$ & $\begin{array}{l}\text { Inform } \\
\text { asi: } \\
\text { klinik, } \\
\text { fasilitas } \\
\text { dokter, } \\
\text { perawa } \\
\text { t, } \\
\text { apoteke } \\
\text { r, dan } \\
\text { pasien }\end{array}$ \\
\hline 2 & $\begin{array}{l}\text { A } \\
\text { po } \\
\text { te } \\
\text { ke } \\
\text { r }\end{array}$ & $\begin{array}{l}\text { Data obat, } \\
\text { pembelia } \\
\text { n, } \\
\text { penjualan } \\
\text {, dan }\end{array}$ & $\begin{array}{l}\text { Sim } \\
\text { pan, } \\
\text { Upd } \\
\text { ate, } \\
\text { Dele }\end{array}$ & $\begin{array}{l}\text { Inform } \\
\text { asi: } \\
\text { obat, } \\
\text { pembel } \\
\text { ian, }\end{array}$ \\
\hline
\end{tabular}




\begin{tabular}{|c|c|c|c|c|}
\hline & & $\begin{array}{l}\text { persediaa } \\
\mathrm{n}\end{array}$ & $\begin{array}{l}\text { te, } \\
\text { hitu } \\
\text { ng } \\
\text { pers } \\
\text { edia } \\
\text { an }\end{array}$ & $\begin{array}{l}\text { penjual } \\
\text { an, dan } \\
\text { persedi } \\
\text { aan }\end{array}$ \\
\hline 3 & $\begin{array}{l}\mathrm{D} \\
\text { ok } \\
\text { ter }\end{array}$ & $\begin{array}{l}\text { data } \\
\text { penyakit, } \\
\text { data } \\
\text { pasien, } \\
\text { data } \\
\text { rekam } \\
\text { medis, } \\
\text { data } \\
\text { resep, dan } \\
\text { data } \\
\text { rujukan }\end{array}$ & $\begin{array}{l}\text { Sim } \\
\text { pan, } \\
\text { Upd } \\
\text { ate, } \\
\text { Dele } \\
\text { te }\end{array}$ & $\begin{array}{l}\text { Inform } \\
\text { asi: } \\
\text { penyak } \\
\text { it, } \\
\text { pasien, } \\
\text { rekam } \\
\text { media, } \\
\text { resep } \\
\text { dan } \\
\text { rujukan }\end{array}$ \\
\hline 4 & $\begin{array}{l}\mathrm{Pe} \\
\mathrm{ra} \\
\mathrm{wa} \\
\mathrm{t}\end{array}$ & $\begin{array}{l}\text { Data } \\
\text { perawatan } \\
\text {, data } \\
\text { ruangan, } \\
\text { data } \\
\text { pasien }\end{array}$ & $\begin{array}{l}\text { Sim } \\
\text { pan, } \\
\text { Upd } \\
\text { ate, } \\
\text { Dele } \\
\text { te }\end{array}$ & $\begin{array}{l}\text { Inform } \\
\text { asi: } \\
\text { perawa } \\
\text { tan, } \\
\text { ruanga } \\
n, \text { dan } \\
\text { pasien }\end{array}$ \\
\hline 5 & $\begin{array}{l}\text { M } \\
\text { an } \\
\text { ag } \\
\text { er }\end{array}$ & Disposisi & $\begin{array}{l}\text { Sim } \\
\text { pan, } \\
\text { Upd } \\
\text { ate, } \\
\text { Dele } \\
\text { te }\end{array}$ & $\begin{array}{l}\text { Lapora } \\
\mathrm{n} \\
\text { klinik, } \\
\text { apotik, } \\
\text { perawa } \\
\text { tan, } \\
\text { keuang } \\
\text { an }\end{array}$ \\
\hline 6 & $\begin{array}{l}\mathrm{Pa} \\
\text { sie } \\
\mathrm{n}\end{array}$ & Antrian & & $\begin{array}{l}\text { Inform } \\
\text { asi: } \\
\text { antrian, } \\
\text { penyak } \\
\text { it, } \\
\text { pasien, } \\
\text { rekam } \\
\text { media, } \\
\text { resep } \\
\text { dan } \\
\text { rujukan }\end{array}$ \\
\hline
\end{tabular}

Pada tabel 3.2 memperlihatkan identifikasi eksternal entity berdasarkan masukan, interaksi proses yang dapat dilakukan, dan keluaran dari sistem yang dapat dilihat.

\section{Kebutuhan Non-Fungsional}

Berdasarkan identifikasi kebutuhan fungsional sebelumnya, peneliti mengidentifikasi kebutuhan nonfungsional sistem informasi poliklinik terpadu sebagai penunjang sistem.

Tabel 3.3 Daftar Kebutuhan Non Fungsional Sistem.

\begin{tabular}{|c|c|c|c|c|c|}
\hline $\begin{array}{l}\mathrm{N} \\
\text { o. }\end{array}$ & $\begin{array}{l}\text { Kebu } \\
\text { tuhan }\end{array}$ & $\begin{array}{l}\text { Spesi } \\
\text { fikasi }\end{array}$ & $\begin{array}{l}\text { Manfa } \\
\text { at }\end{array}$ & $\begin{array}{l}\text { Mini } \\
\text { mum }\end{array}$ & $\begin{array}{l}\mathrm{K} \\
\text { et }\end{array}$ \\
\hline 1. & $\begin{array}{l}\text { Web } \\
\text { Serve } \\
\mathrm{r}\end{array}$ & $\begin{array}{l}\text { HTT } \\
\mathrm{P}\end{array}$ & $\begin{array}{l}\text { Sebaga } \\
\text { i server } \\
\text { tempat } \\
\text { berjala } \\
\text { n } \\
\text { aplikas } \\
\text { i }\end{array}$ & $\begin{array}{l}\text { Apac } \\
\text { he } 2 \\
\text { atau } \\
\text { setar } \\
\text { a }\end{array}$ & \\
\hline 2. & $\begin{array}{l}\text { MyS } \\
\text { QL }\end{array}$ & $\begin{array}{l}\text { SQL, } \\
\text { relasi } \\
\text { data }\end{array}$ & $\begin{array}{l}\text { Menge } \\
\text { lolah } \\
\text { dan } \\
\text { menyi } \\
\text { mpan } \\
\text { data } \\
\text { secara } \\
\text { berelas } \\
\text { i } \\
\end{array}$ & $\begin{array}{l}\text { MyS } \\
\text { QL } \\
\text { Serv } \\
\text { er } \\
5.5 \\
\text { atau } \\
\text { setar } \\
\text { a }\end{array}$ & \\
\hline 3. & $\begin{array}{l}\text { Kom } \\
\text { puter }\end{array}$ & $\begin{array}{l}\text { x86 / } \\
\text { x64, } \\
\text { mem } \\
\text { ory } \\
\text { DDR } \\
2 \\
\text { hardi } \\
\text { sk } \\
5000 r \\
\text { pm }\end{array}$ & $\begin{array}{l}\text { Sebaga } \\
\mathrm{i} \\
\text { tempat } \\
\text { berjala } \\
\mathrm{n} \\
\text { aplikas } \\
\mathrm{i} \text { dan } \\
\text { penyi } \\
\text { mpana } \\
\text { n fisik }\end{array}$ & $\begin{array}{l}\text { Intel } \\
\text { Penti } \\
\text { um } \\
\text { Core } \\
2 \\
\text { Duo, } \\
512 \\
\text { MB, } \\
20 \\
\text { GB }\end{array}$ & \\
\hline
\end{tabular}

\section{Desain Proses Sistem}

Pada gambar 3.2 menunjukkan diagram konteks dengan entitas eksternal yang berinteraksi dengan sistem berdasarkan aliran data masing-masing.

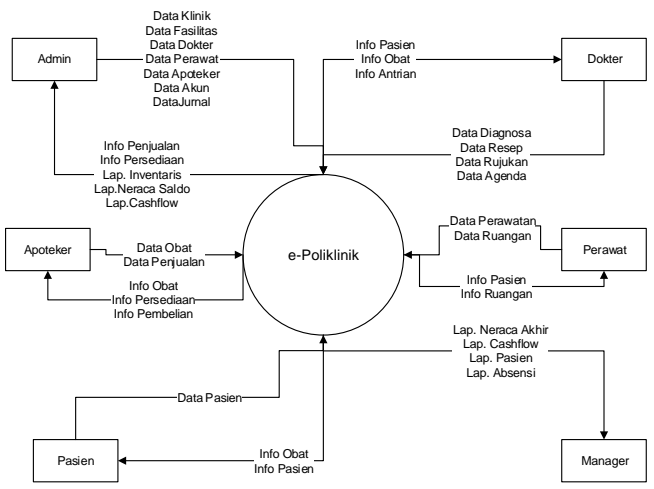


Gambar 3.2 Diagram Konteks ePoliklinik.

Pada gambar 4.2 menunjukkan diagram HIPO (Hierarchycal Input Process Output) dengan e-Poliklinik sebagai proses utamanya dan diturunkan menjadi beberapa level proses.

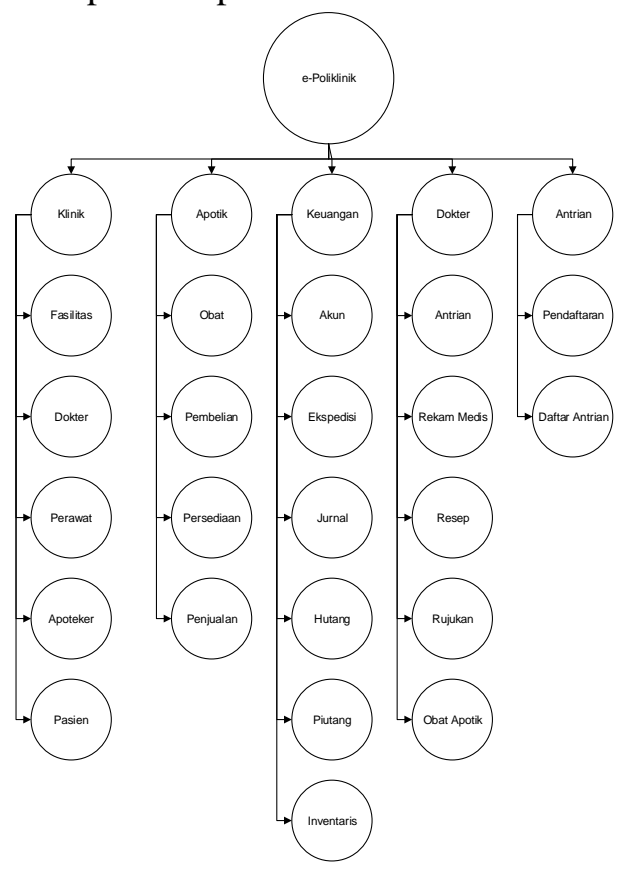

Gambar 3.3 Diagram HIPO atau Berjenjang e-Poliklinik

\section{Pembangunan Sistem}

Hasil pembangunan sistem dibuat HTML5 memanfaatkan template Clinico dengan bahasa pemrograman PHP serta MySQL Server 5.6.

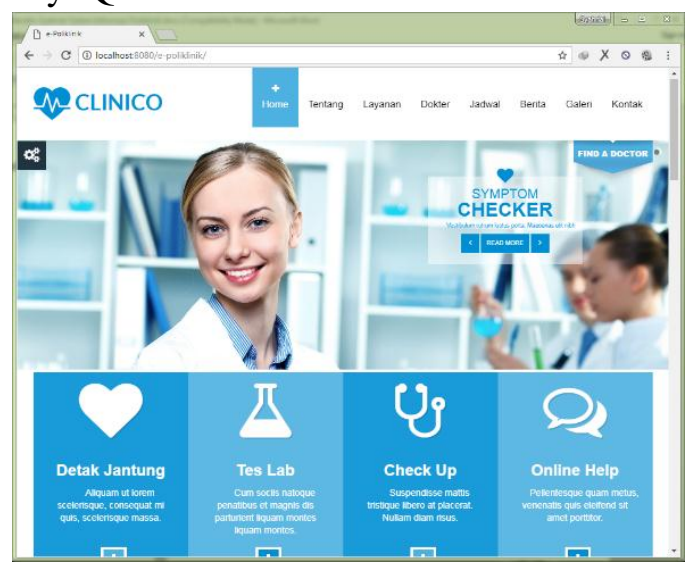

Gambar 3.4 Tampilan Frontend ePoliklinik Halaman Home.

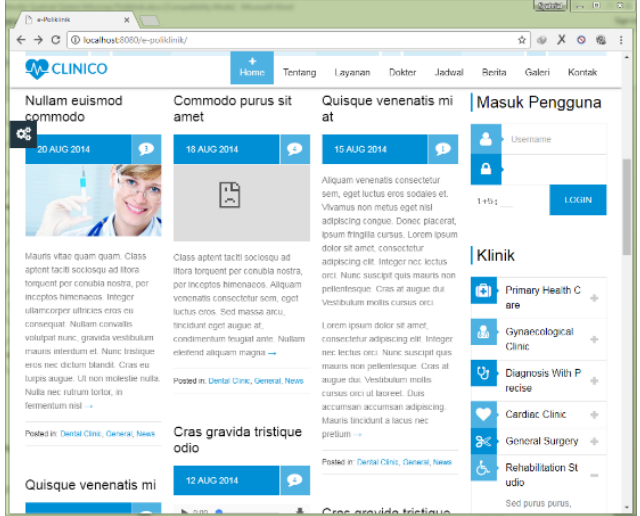

Gambar 3.5 Tampilan Frontend ePoliklinik Halaman Home Lanjutan.

\section{KESIMPULAN DAN SARAN}

Aplikasi sistem informasi poliklinik terpadu - e-Poliklinik dapat menampilkan informasi berupa antrian, informasi dokter, jadwal, obat dan lainnya. Aplikasi ini dapat menunjukkan informasi antrian terkini bagi umum dan pendaftaran antrian bagi pasien terdaftar. Aplikasi ini dapat mempermudah pasien terdaftar untuk mendaftar antrian, melihat rekam medis, resep dan kebutuhan informasi lainnya. Aplikasi ini dapat menjadi sarana yang menjembatani antara pasien dan dokter tanpa harus ke poliklinik dengan adanya teknologi web. Sistem ini perlu dikembangkan tampilan, load, penjelasan lebih detail perihal aplikasi. Pengembangan lebih lanjut dibuatkan sistem informasi poliklinik untuk kebutuhan berbagai pelayanan medis.

\section{DAFTAR PUSTAKA}

[1] MENKES, SK MENKES, Jakarta: MENKES, 1992.

[2] R. V. Imbar dan Y. Kurniawan, "Perancangan Sistem Informasi Pelayanan Medis Rawat Jalan Poliklinik Kebidanan dan Kandungan pada RSUD Kota Batam," Jurnal Sistem Informasi, Vol.7, No.1, pp. 53-67, 2012. 
[3] R. E. I. Bagaskara, W. A. Syafei dan R. R. Isnanto, "PERANCANGAN SISTEM INFORMASI POLIKLINIK," TRANSIENT, VOL.1, NO. 4, ISSN: 2302-9927, 349, pp. 1-7, 2012.

[4] M. Andriyas, "Rancang Bangun Sistem Informasi Laboratorium Klinik Berbasis Web Pada Laboratorium Klinik Utama SAFIRAH Sidoarjo," Jurusan Sistem Informasi, Sekolah Tinggi Manajemen Informatika dan Teknik Komputer Surabaya- Tidak diterbitkan, Surabaya, 2012.

[5] B.

B. Budiawan, "PEMBANGUNAN SISTEM INFORMASI KLINIK GIGI DENTAL SMILE MENGGUNAKAN

FRAMEWORK

CODEIGNITER," Tugas Akhir Prodi Teknik Informatika, Fakultas Teknologi Industri, Universitas Atma Jaya - Tidak Diterbitkan, Yogyakarta, 2013.

[6] R. R. M. Salim, "PENGEMBANGAN SISTEM INFORMASI KLINIK BERBASIS WEB," dalam Seminar Nasional Sistem Informasi Indonesia, 2013.

[7] S. A. Wuner, R. Sengkey dan O. A. Lantang, "ANALISA DAN PERANCANGAN SISTEM INFORMASI POLIKLINIK UNSRAT BERBASIS WEB," 2014.

[8] B. S. Prakoso, "SISTEM INFORMASI ADMINISTRASI KLINIK NGUDI WARAS PURWODADI BERBASIS WEB," Makalah PROGRAM STUDI TEKNIK INFORMATIKA FAKULTAS KOMUNIKASI DAN INFORMATIKA UNIVERSITAS
MUHAMMADIYAH

SURAKARTA - Tidak

Diterbitkan, Surakarta, 2014.

[9] A. H. Arrosid, "SISTEM INFORMASI POLIKLINIK PADA KLINIK CITO INDRAPASTA SEMARANG," Skripsi Program Studi Sistem Informasi, Fakultas Ilmu Komputer Universitas Dian Nuswantoro Tidak Diterbitkan, Semarang, 2014.

[10] E. S. Sumariani, “ANALISIS KEBUTUHAN PERENCANAAN SISTEM INFORMASI KESEHATAN PADA BIDANG PELAYANAN DINAS KESEHATAN KABUPATEN BOYOLALI," Artikel PROGRAM STUDI KESEHATAN MASYARAKAT FAKULTAS ILMU KESEHATAN UNIVERSITAS MUHAMMADIYAH SURAKARTA - Tidak Diterbitkan, Surakarta, 2015.

[11] R. Sutjiadi, "Perancangan dan Pembuatan Aplikasi Sistem Klinik Berbasis Web (Studi Kasus Klinik dr. Rida)," Jurnal TEKNIKA, pp. 35-43, 2015.

[12] Tominanto, "PERANCANGAN SISTEM INFORMASI PENDAFTARAN RAWAT JALAN KLINIK," Jurnal Manajemen Informasi Kesehatan Indonesia Vol. 3 No.2, SSN: 2337 6007 (online); 2337-585X (Printed), pp. 32-38, 2015.

[13] I. P. A. Y. Permana, "Rancang Bangun Sistem Informasi Klinik Praktik Dokter Berbasis Web," Jurnal Teknologi Informasi dan Komputer, Volume1, Nomor 2, pp. 127-133, 2015.

[14] U. A. Faruq, "RANCANG BANGUN APLIKASI REKAM 
MEDIS

UNIVERSITAS

POLIKLINIK

TRILOGI,"

JURNAL INFORMATIKA Vol. 9, No. 1, pp. 1017-1027, 2015.

[15] A. S. Maryati, S. K. Sari dan A. P. Kurniawan, "SISTEM

INFORMASI KLINIK BHAKTI SEHAT BERBASIS WEB," dalam e-Proceeding of Applied Science : Vol.1, No.3, ISSN : 2442-5826, 2015.

[16] R. Sinaga dan Nurhadi, "ANALISIS DAN PERANCANGAN SISTEM INFORMASI REKAM MEDIS PADA KLINIK AKPER KESDAM II/SRIWIJAYA GARUDA PUTIH," Jurnal
Manajemen Sistem Informasi Vol 1 No. 1, ISSN : 2540-8011, pp. 67-79, 2016.

[17] Jogiyanto, Analisis \& Desain Sistem Informasi, Yogyakarta: Andi Offset, 2005.

[18] Loudon, dalam Sistem Informasi Manajemen Mengelola Perusahaan Digital, Jakarta, Pearson education, 2007, p. 15.

[19] MENKES, PERMENKES, Jakarta, 1989.

[20] Sjamsuhidajat, Manual rekam medis, Jakarta: Konsil Kedokteran Indonesia, 2006. 